\title{
First record of Phasmarhabditis sp. from eggs of Eobania vermiculata (Müller) snails in Egypt and their response to host size
}

\author{
Karima Mahmoud Azzam* (iD and Nema El-Abd
}

\begin{abstract}
Background: Gastropods are very prevalent animals. In Egypt, terrestrial snails represent important economic pests, infesting and causing severe damages to ornamental plants, orchard trees, vegetables, and field crops. The overuse of molluscicides against these destructive pests leads to more environmental pollution. Therefore, searching for biological control agents became necessary to avoid the hazard of chemical molluscicides. Phasmarhabditis hermaphrodita, isolated from slugs was used as a bio-control agent against snails and slugs. Few investigations available on gastropod egg parasites. Therefore, the present study interested in the isolation of parasitic nematodes from the snail eggs to study their possible role as biological control agents for gastropod pests.

Results: This is the first record to isolate the snail parasitic nematode, Phasmarhabditis sp., from eggs of the Egyptian terrestrial snail, Eobania vermiculata (Müller). Infectivity of this nematode was investigated for eggs, juvenile and mature snails, E. vermiculata and Limax flavus L. slugs, and also eggs of the non-local species, Achatina fulica Bowdich and one adult of it was only available. The investigation revealed a capability of the isolated nematode to infect and kill E. vermiculata snail, L. flavus slugs, and their eggs. Also, it could infect and kill the eggs of non-local snail species, A. fulica, and its only individual adult available which was obtained from an agricultural quarantine sample. The results indicated also that released individuals of the nematodes, recovered from snails, were significantly larger in size than those recovered from eggs and vice versa.

Conclusion: It could be concluded that the isolated parasitic nematode may be able to play a role in controlling different stages of the gastropods including eggs. This make the control more effective in protecting host plants before the pest causing damage. The nematode was more effective on local pest species than non-local species. Moreover, the size of the parasite was proportional with the size of the host pest.
\end{abstract}

Keywords: Phasmarhabditis, Eobania vermiculata (Müller), Limax flavus L., Eggs, Size, Biological control

\section{Background}

Gastropods are prevalent animals that belong to Phylum Mollusca, which represent the second largest Phylum after Arthropods (Lydeard et al. 2004). In Egypt, terrestrial snails represent important economic pests that were prevalent in many governorates, infesting and causing severe damages to ornamental plants, orchard trees,

\footnotetext{
*Correspondence: azzamkarima@gmail.com; karima.azzam@arc.sci.eg; k_azzam@hotmail.com

Plant Protection Research Institute, Agricultural Research Center, Dokky, Giza, Egypt
}

vegetables, and field crops (Desoky 2018). Overuse of molluscicides against these destructive pests has contributed to more environmental pollution (Godan 1983). Therefore, searching for effective biological control The snail parasitic nematode, Phasmarhabditis tawfiki Azzam, was first recorded and described by Azzam (2003). This nematode was isolated from E. vermiculata is a Phasmarhabditis hermaphrodita (Schneider, 1859) is a parasitic nematode isolated from slugs and capable of killing several species of slug pests (Wilson et al. 1993). 
Coupland (1995) studied the susceptibility of helicid snails infected with $P$. hermaphrodita and found that Monacha cantiana (Müller), Helix aspersa Müller, Theba pisana (Müller), Cernuella virgata (DaCosta), and Cochlicella acuta (Müller) could be killed by $P$. hermaphrodita in laboratory bioassays. Phasmarhabditis hermaphrodita was used as a bio control agent against snails and slugs (Rae et al. 2007). Daubaylia species are nearly always parasitic for freshwater snails of Planorbidae, (Holovachov et al. 2015) and D. bonaerensis recorded in Helix aspersa Müller (Camino and Gonzàlez 2011). Azzam (2006) recorded 16 snail species and 3 slugs infested about 64 species of different plants in Egypt. She recorded also 5 species of snail parasitic nematodes including, $P$. tawfiki, $P$. hermaphrodita, Rhabditis sp., Diploscapter sp., and Cephalobus sp. Azzam and Abd El-Hady (2018) recorded 7 snail species and 3 slug species infesting about 47 species of plants in 7 governorates in Egypt. All terrestrial snails cause damages to their host plants by feeding on leaves, blooms, flowers, fruits, trunks, limbs, and even on barks.

Since few studies are available on the gastropod egg parasites, the present study aimed to isolate parasitic nematodes from snail eggs to evaluate their possible role as biological control agents against gastropod pests and their eggs.

\section{Methods}

\section{Samples collection}

Samples of terrestrial snails and slugs were collected from infested plants by hand picking from Cairo, Egypt, during 2016-2019. Snails and slugs were identified according to Godan (1983); Cowie (2002); Auffenberg and Stange (2009); Baker Skinner Park (2009); and Azzam and Tawfik (2011).

\section{Rearing of gastropods}

After collecting and identifying the gastropod samples, they were washed thoroughly using a fine metallic net under strong stream of tap water and then washed again by distilled water. Some individuals were placed in a Petri-dish with distilled water and examined under a research microscope, to check for the presence of the microorganisms. This process was repeated several times until the complete removal of all external associated organisms.

Rearing of Eobania vermiculata (Müller) snail and Limax flavus $\mathrm{L}$. slug were carried out by placing the examined individuals in plastic cages, sterilized with ethanol alcohol, substrated with sterilized clay, and irrigated by distilled water. After egg laying, the eggs were washed gently by distilled water and transferred to sterilized Petri dishes contained sterilized clay.

The Petri dishes were then placed in a dark place until hatching. The newly hatched gastropods were transferred gently to new sterilized cages as mentioned before and supplied with some lettuce leaves after washing them thoroughly by a strong stream of tap water to remove associated organisms then washed again by distilled water and introduced to the newly hatching gastropods.

\section{Isolation of nematodes from eggs}

The collected snail eggs were gently washed by tape water then distilled water and examined under a microscope to remove any external associated nematodes or any microorganisms. If microscopic examination showed any organisms association, the egg washing should be repeated again and again until eggs are looked totally free from these organisms. After the complete removal of external associated microorganisms, the eggs were screened for parasitic nematodes by placing them individually in small Petri-dishes, $6 \mathrm{~cm}$ in diameter, with little distilled water $(1 \mathrm{ml})$. The dishes were examined daily by a microscope for releasing nematodes and the distilled water was recompleted. Every 3 days, two eggs were dissected to check the presence of the parasitic nematodes inside. The isolated nematodes were identified according to Andrassy (1976), Azzam (2003), Sudhaus (2018), Tandingan De Ley et al. (2014, 2016), and Singh et al. (2019).

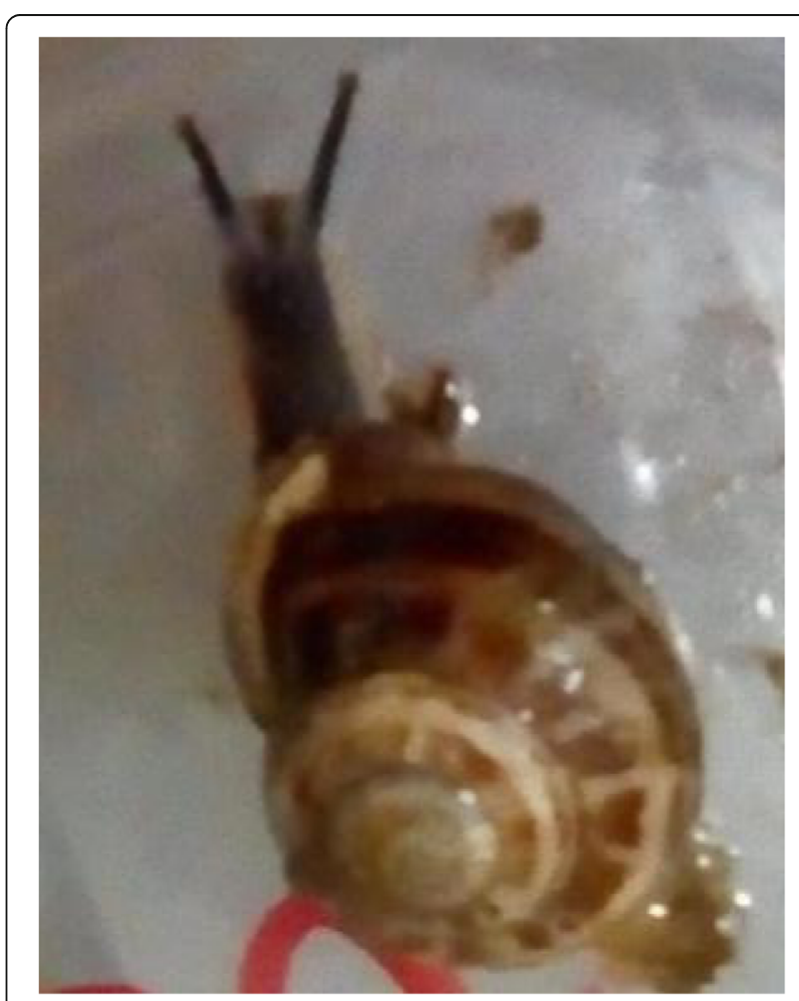

Fig. 1 Adult of E. vermiculata 


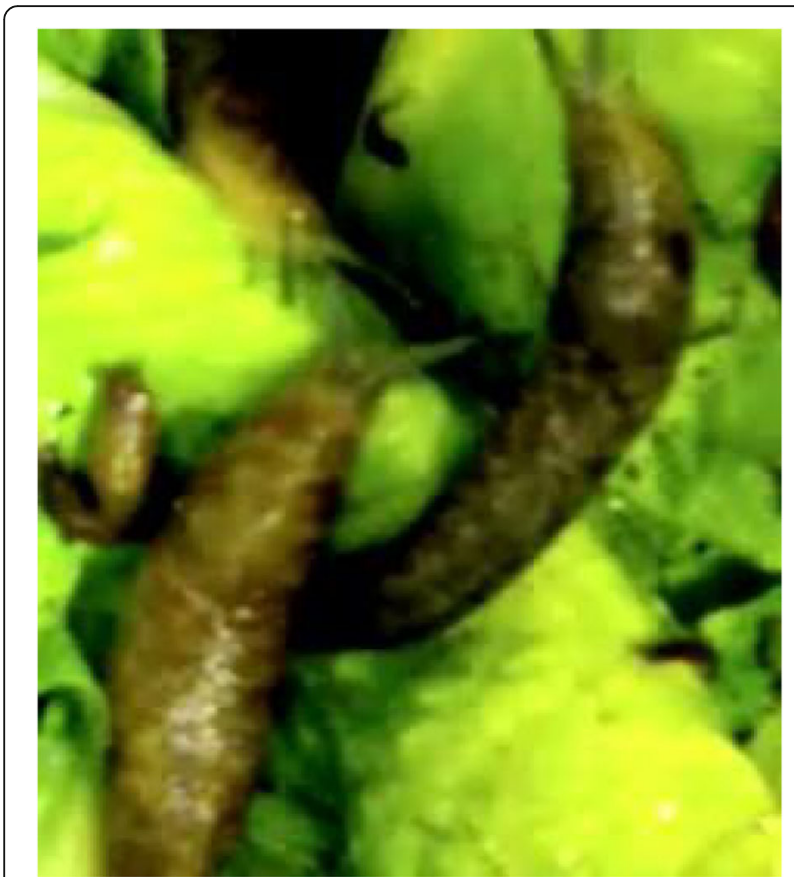

Fig. 2 Adult of L. flavus

\section{Count of nematodes}

Counting of the released nematodes of recovering individuals, to be used in the infection of tested species and stages, was carried out by taking a $5 \mu$ l of the nematode suspension (by means of a micropipette) after shaking it thoroughly, it was placed on micrometer slide, examined microscopically, and counted the number of nematodes. This procedure was repeated 4 times. The mean number was calculated and multiplied by 200 to estimate the number of nematodes in $1 \mathrm{ml}$. To prepare adjusting concentration, some of this solution may be diluted to the concentration needed.

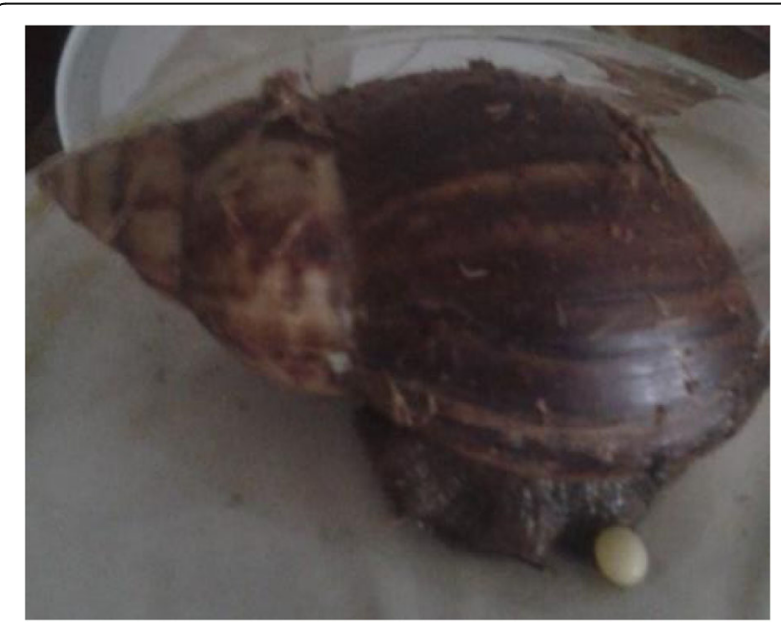

Fig. 3 Adult of A. fulica

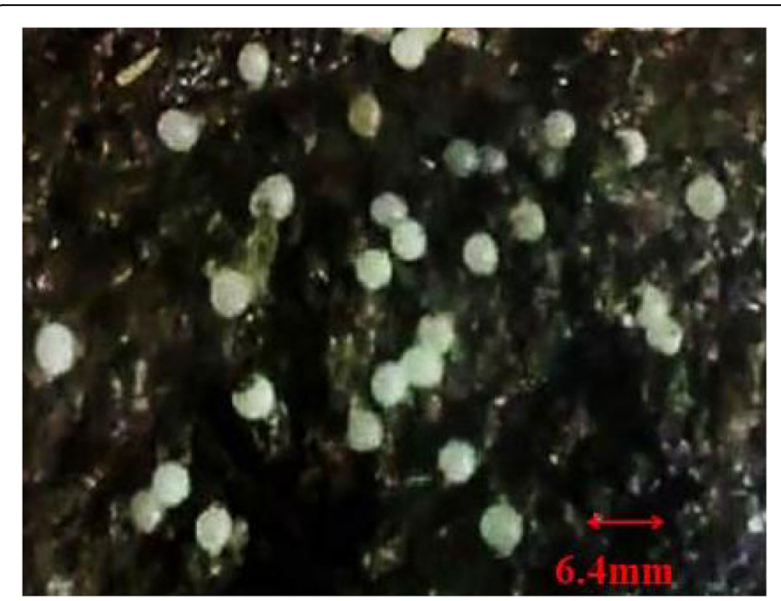

Fig. 4 Healthy eggs of E. vermiculata

\section{Infection of snails and eggs}

The isolated nematodes infectivity was investigated toward lab bred of E. vermiculate snails (Fig. 1), L. flavus slug (Fig. 2), and non-local giant terrestrial snails, Achatina fulica Bowdich (Fig. 3) which have not been found in Egypt (one snail obtained from the Agricultural Quarantine Office). This sample deposited 125 eggs in the laboratory during examination and identification. These eggs were treated as mentioned above and exposed to infection by the isolated nematodes.

The nematodes were also tested for the infection of eggs of the abovementioned three species (Figs. 4, 5, and 6) respectively at $22 \pm 2{ }^{\circ} \mathrm{C}$, using the same technic previously described by Azzam (1998).

The relative infectivity of the isolated nematodes to the abovementioned gastropods was determined by placing the 20 lab bred individuals of each species and stages individually in a Petri dish $(9.5 \mathrm{~cm}$ in diameter for snails, slugs, and eggs). A little amount of distilled water contained isolated nematodes $(1.5 \mathrm{ml}$ contained $500 \mathrm{I}$.J. S. for snail and slugs and $0.5 \mathrm{ml}$ contained 100 I.J. S. for

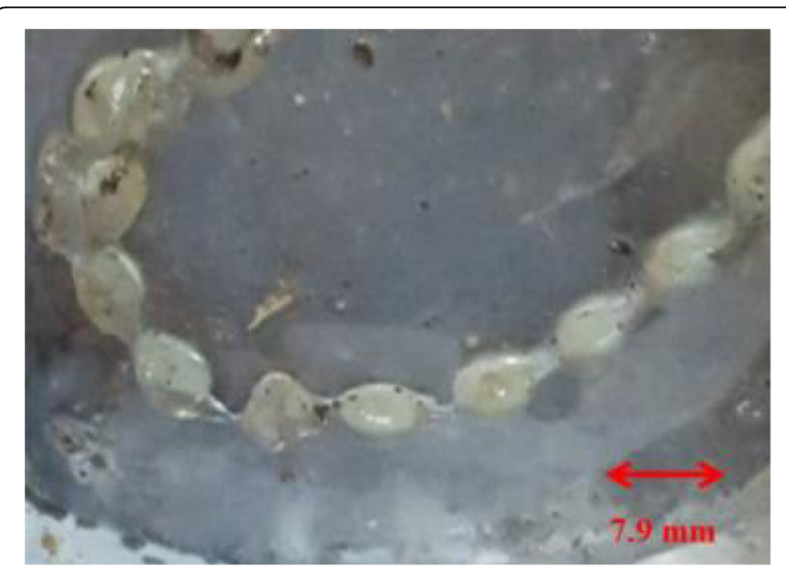

Fig. 5 Healthy eggs of L. flavus 


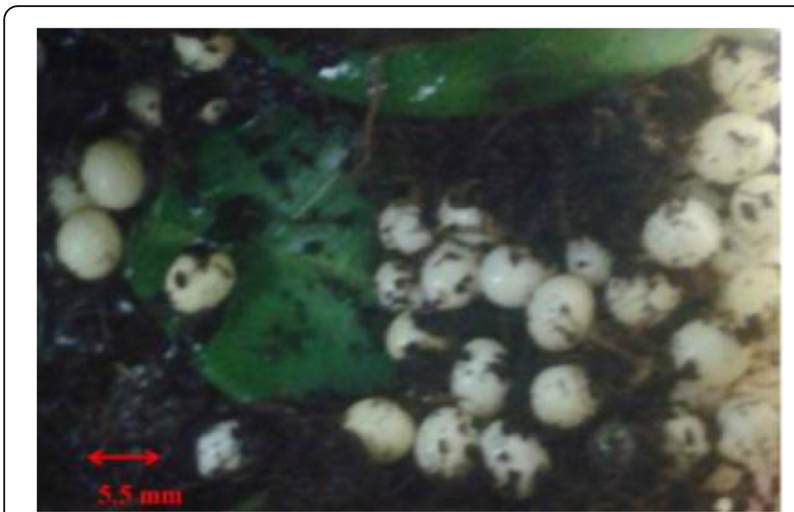

Fig. 6 Healthy eggs of A. fulica

eggs) were placed in their relevant Petri dishes. Another 10 individuals from each species were treated similarly to abovementioned groups but using distilled water only without adding nematodes as control groups.

For the infection of the individual adult of the nonlocal giant terrestrial snail, A. fulica (Fig. 3), 2500 I.J.S. in $3 \mathrm{ml}$ was added into a Petri dish (14 $\mathrm{cm}$ in diameter). The concentration increased than those used for adults of E. vermiculata and L. flavus, to be adequate for its large size. The size of the Petri dish and the volume of nematode suspension were also increased for the same reason. For the comparison of the suitability of this parasitic nematode to infect different hosts, the following capacity index was calculated for each host guided by Azzam (1998).

$$
(\mathrm{C} . \mathrm{I}=\mathrm{M} \times \mathrm{R} / \mathrm{T})
$$

where $M$ is the mortality rate of pests at the end of 6 weeks, $R$ is the percentage recovery of the infected stage of nematodes in infected individuals, and $T$ is the time needed for the nematodes to reach the infective stage after initial infection.

\section{Statistical analysis}

The time needed for the nematodes to reach infective stage after initial infection, body length of nematode in different stages, ratios of mortality, and individuals recovered nematodes were analyzed by ANOVA and $T$ test value using PSPP program.

\section{Results}

As shown in Table 1, the parasitic nematode could infect all species and stages exposed, killing 100\% from E. vermiculata eggs, and all individuals of the other species and stages. The table showed also that all infected species and stages recovered the parasitic nematode in different ratios. About $50 \%$ of A. fulica eggs and 100\% from other species and stages were released infective stage of nematode. The lower ratio of Achatina eggs may be attributing to the hardness of the calcified egg capsule which was soft for the other species. The results indicated that all species were suitable to serve as hosts for the parasitic nematode, consequently the suitability of isolated nematode to control these pests at their different stages. Statistically, there was a highly significant difference between ratios and individuals recovered nematodes of $A$. fulica eggs and each of the other infected species and stages.

Concerning the time from initial infection to recovered infective stage, the only individual available of $A$. fulica snail recorded the longest period, followed by its eggs then adult of L. flavus, while eggs of E. vermiculata recorded the shortest period. Statistically, non-significant differences between period for L. flavus and juvenile of $E$. vermiculata and between periods for adult $E$.

Table 1 Capability of Phasmarhabditis sp. to infect different species and stages of terrestrial gastropods under laboratory conditions of $22 \pm 2{ }^{\circ} \mathrm{C}$ and $60 \pm 5$ R.H. \%

\begin{tabular}{|c|c|c|c|c|c|c|c|}
\hline Species and stage & Mortality \% & $\begin{array}{l}\text { Time from infection to } \\
\text { recovered nematodes }\end{array}$ & $\begin{array}{l}\text { Ability of dead } \\
\text { individuals to } \\
\text { release nematodes }\end{array}$ & $\begin{array}{l}\text { Rate of } \\
\text { individuals } \\
\text { released } \\
\text { nematodes \% }\end{array}$ & $\begin{array}{l}\text { Ability of } \\
\text { released } \\
\text { nematodes to } \\
\text { infect healthy } \\
\text { pests }\end{array}$ & $\begin{array}{l}\text { Capacity } \\
\text { index }\end{array}$ & Rank \\
\hline Eggs of E. vermiculata & $100 \%$ & $7.32 \pm 0.95$ c (6-9) & + & $100 \%$ & + & 1366.12 & 1 \\
\hline Eggs of L. flavus & $100 \%$ & $8.4 \pm 1.05$ a $(7-10)$ & + & $100 \%$ & + & 1190.48 & 3 \\
\hline Eggs of $A$. fulica & $100 \%$ & $19.2 \pm 1.74(15-21)$ & + & 50 & + & 260.41 & 7 \\
\hline Juvenile snail of E. vermiculata & $100 \%$ & $7.95 \pm 1$ a $(6-10)$ & + & 100 & + & 1257.86 & 2 \\
\hline Juvenile slug of L. flavus & $100 \%$ & $10.8 \pm 1.15$ b (9-13) & + & 100 & + & 925.93 & 5 \\
\hline Mature snail of E. vermiculata & $100 \%$ & $10.5 \pm 1$ b (9-12) & + & 100 & + & 952.38 & 4 \\
\hline Mature slug of L. flavus & $100 \%$ & $14.4 \pm 1.43 \mathrm{~d}(12-17)$ & + & 100 & + & 694.44 & 6 \\
\hline Mature A. fulica* & $100 \% *$ & $40 * \mathrm{e}$ & + & $100 *$ & + & $250^{*}$ & 8 \\
\hline
\end{tabular}

Means had the same letter were in significant differences

*Non-local species, only single individual were available from agricultural quarantine sample 
Table 2 Size in micrometer of nematodes recovering from eggs and adult of some gastropods

\begin{tabular}{llll}
\hline $\begin{array}{l}\text { Gastropod } \\
\text { stage }\end{array}$ & \multicolumn{3}{l}{ Body length of recovered nematodes } \\
\cline { 2 - 4 } & Female & Male & Infective stage \\
\hline Eggs & $1180.5 \pm 164.06$ & $1016 \pm 193.11$ & $767 \pm 91.6$ \\
Adults & $1916 \pm 319.03$ & $1313 \pm 178.64$ & $941 \pm 126.79$ \\
$T$ value & 7.34 & 3.32 & 4.93 \\
Significant & 0.001 & 0.01 & 0.001 \\
\hline
\end{tabular}

vermiculata and juvenile of L. flavus, while highly significant differences among other data were found.

Concerning capacity index, lowest C.I. (250) was reported for the only individual available of A. fulica, followed by its eggs (260.41). The highest capacity index (1366.12) was recorded for eggs of E. vermiculata, the natural host of the parasitic nematode, followed by juvenile of the same species and then eggs of the slug $L$. flavus. The juvenile and mature slug ranked after mature snails $E$. vermiculata. These results indicated the more suitability of eggs and juvenile of $E$. vermiculata and $L$. flavus and mature snails as hosts for the isolated parasitic nematode than mature slugs, which found more suitable than snail and eggs of the non-local species, $A$. fulica. The results indicated the suitability of isolated parasitic nematode to control gastropods at their different stages including egg stage, thus, make the control programs more effective in protecting host plants before the pest cause damage. The results indicated also that the isolated nematode were more effective on local pest than non-local pests.

Through the investigation, it was noticed that the dead eggs of all species changed in color, appeared yellowish to reddish (Figs. 7, 8, and 9). Also, some of infected E. vermiculata snails appeared with swollen tentacle (Fig. 10), but the slugs showed swollen foot (Fig. 11). It was also noticed

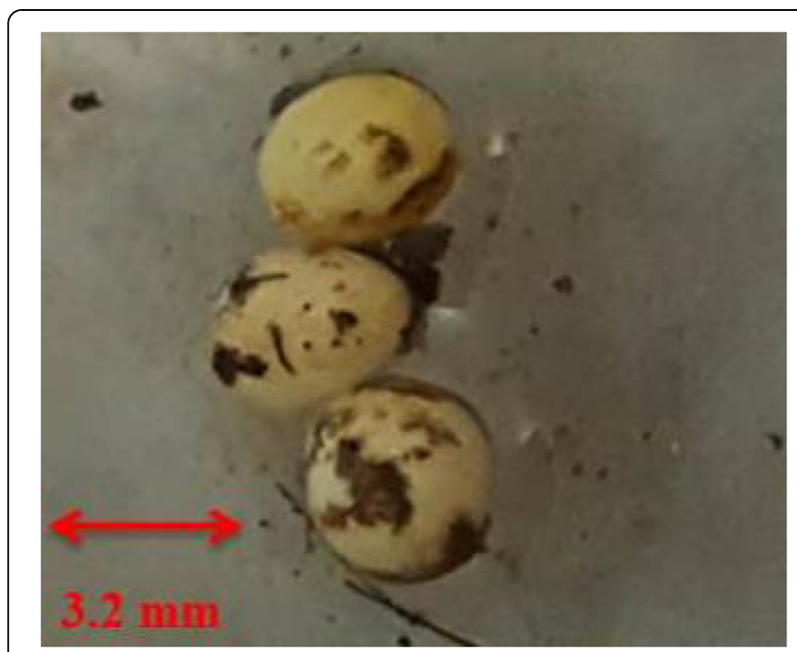

Fig. 7 Dead eggs of E. vermiculata

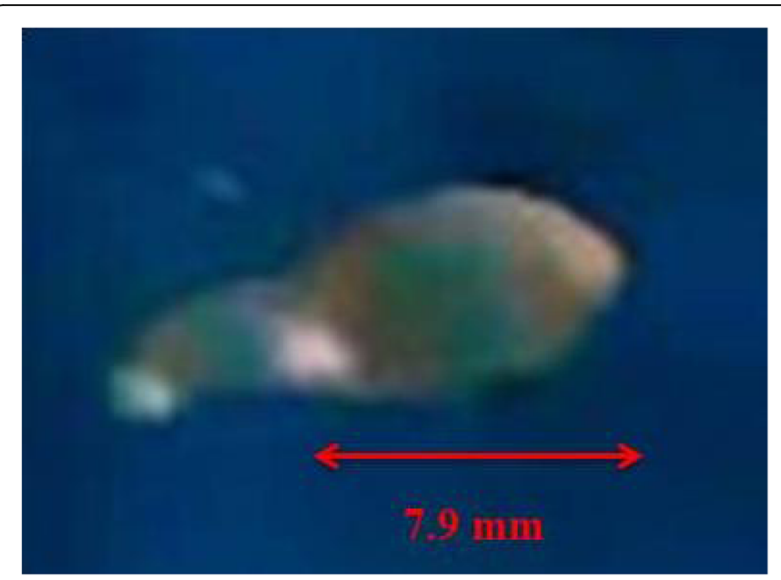

Fig. 8 Dead eggs of L. flavus

that the size of nematodes releasing from snails $E$. vermiculata and L. flavus slug and A. fulica were larger than those released from their eggs (Table 2), but when these large nematodes infected eggs, the eggs released small size nematodes again and vice versa; when the small size nematodes released from eggs infected snails and slugs, they released large size nematodes again. These phenomenon may indicate that the size of host affect the size of parasite. Statistically, high significant differences existed among the body lengths of each of females, males, and infective stages recovered from adult stage of gastropods and those recovered from their eggs.

\section{Discussion}

This is the first record of isolating the snail parasitic nematode, Phasmarhabditis sp., from eggs of the Egyptian terrestrial snails, Eobania vermiculata (Müller). Infectivity of this nematode was investigated for eggs, juvenile and mature stages of different gastropod species

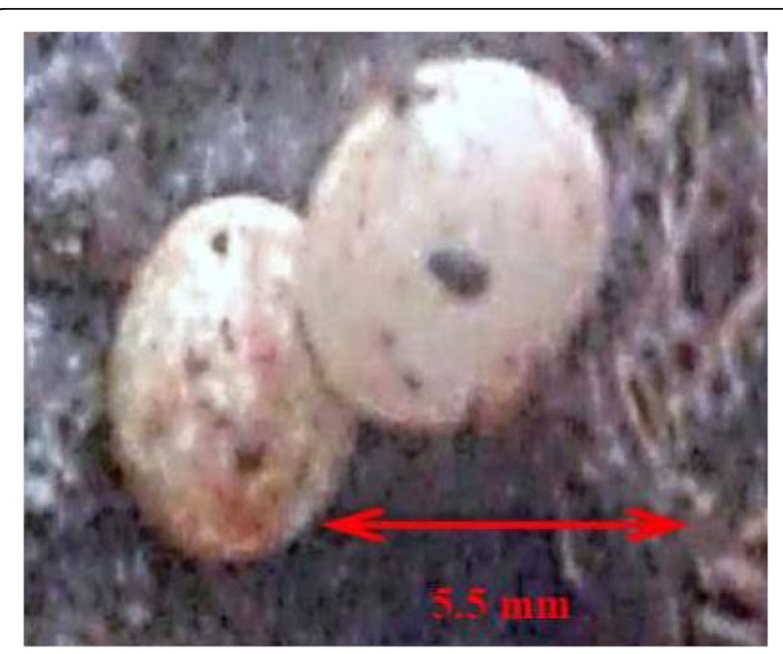

Fig. 9 Dead eggs of A. fulica 


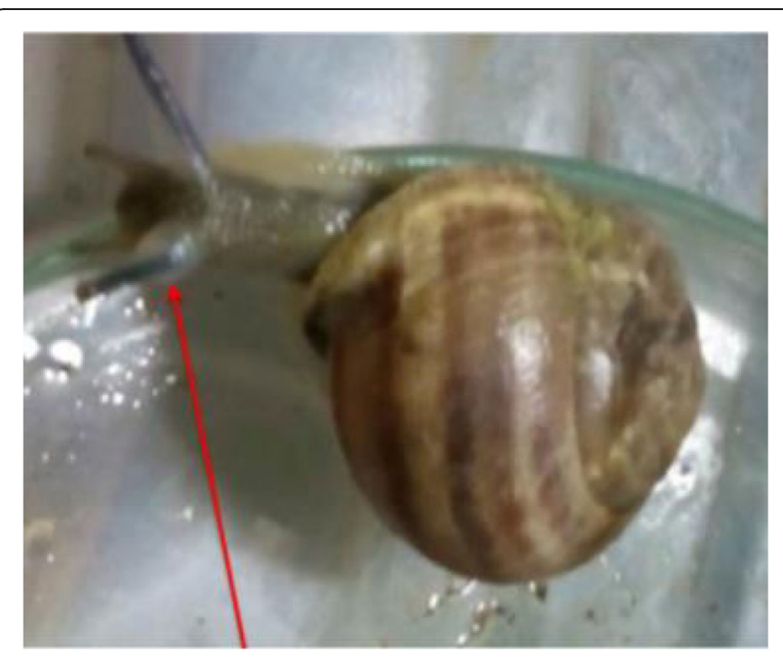

Fig. 10 Infected adult E. vermiculata infected with nematode showing a swollen tentacle

and results indicated the capability of this nematode to infect and kill all species and stages exposed to infection. Azzam (1998) reported the suitability of the parasitic nematode, Rhabditis sp., to infect and kill some terrestrial gastropods, their eggs, and insect larvae and pupae. She found that slugs recorded lower C.I. than snails when infected with the snail parasitic nematode Rhabditis sp., while the insect larvae reported lowest C.I. Coupland (1995) and Rae et al. (2007) found that P. hermaphrodita could kill several snail species and could be used as a biocontrol agent against pest snails and slugs. Wilson et al. (2012) found that the New Zealand strain of P. hermaphrodita infected and killed field-collected Deroceras reticulatum slugs. The associations between nematodes and terrestrial gastropods ranged from accidental phoresis to parasitic or pathogenic relationships (Grewal et al, 2003 and Nermut and Půža 2017).

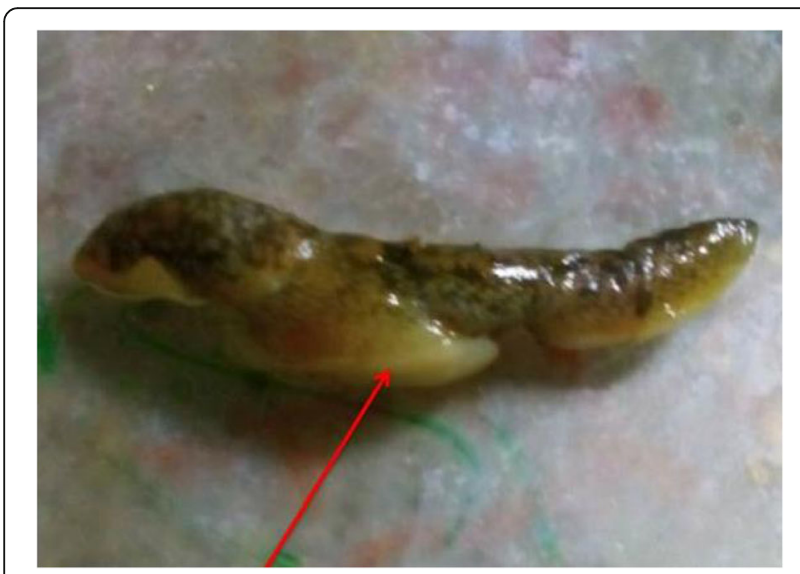

Fig. 11 Dead infected adult L. flavus showed swollen foot

\section{Conclusion}

It could be concluded that Phasmarhabditis sp. can play a role for controlling gastropods in their different stages including egg stage. These make the control more effective in protecting host plants before the pests reaching the economic damage stage. The results indicated that the isolated nematodes found to be more effective on local pests than on non-local pests, and that the size of the host stage is proportional to the size of the parasite.

\section{Abbreviations}

E. vermiculata: Eobania vermiculata (Müller); L. flavus: Limax flavus L.; A. fulica: Achatina fulica Bowdich.; P. tawfiki: Phasmarhabditis tawfiki Azzam (2003); P. hermaphrodita: Phasmarhabditis hermaphrodita (Schneider, 1859); D. bonaerensis: Daubaylia bonaerensis; C.I.: Capacity Index; M: Mortality rate of pests at the end of 6 weeks; R: Percentage recovery of the infective stage of nematodes in infected individuals.; T: The time needed for the nematodes to reach infective stage after initial infection

\section{Acknowledgements}

Not applicable

\section{Authors' contributions}

KA: Identified the gastropods, contribute rearing gastropods, contribute in the examination of the samples, isolate and propagate the nematode, infect different gastropods stage with nematode, record and analyzed the result data, wrote the manuscript. NE: Collect gastropods and their eggs sample from field, prepare the sample for examination, contribute in rearing gastropods, and contribute in recording result data. All authors read and approved the manuscript for submission.

\section{Authors' information}

Karima Mahmoud Azzam Ph.D. is an Emeritus Professor Doctor (Chief of Research) of Malacology and Biological Pest Control at Harmful Animals Department Former Head of the Department from 2013 to 2016. She published about 42 article research in the field of gastropods biological control. She is affiliated to Plant Protection Research Institute, Agricultural Research Center, Dokky, Giza, Egypt.

Nema El-Abd Ph.D. is an Assistant Professor (Senior Researcher) at Harmful Animals Department Plant Protection Research Institute, Agricultural Research Center, Dokky, Giza, Egypt.

\section{Funding}

We have no fund; we fund the investigation from our salaries.

\section{Availability of data and materials}

Not applicable

\section{Declaration}

Ethics approval and consent to participate Not applicable

\section{Consent for publication}

Not applicable. All authors confirm that the content of the manuscript has not been published, or submitted for publication elsewhere.

\section{Competing interests}

The authors declare that they have no competing interests.

Received: 13 November 2020 Accepted: 17 February 2021 Published online: 08 March 2021

\section{References}

Andrassy I (1976) Evolution as a basis for the systematization of nematodes. Pitman Publishing, London, San Francisco, Melbourne, p 288 Auffenberg K, Stange LA (2009) Samoan land snails identification guide http:// www.samoasnails/idguide.asp 
Azzam KM (1998) First record of snail parasitic nematode Rhabditis sp. isolated from Egyptian terrestrial snails and its capability to infect other pests. Egypt J Biol P Contr 8(1):27-29

Azzam KM (2003) Description of Phasmarhabditis tawfiki Azzam n. sp. isolated from Egyptian terrestrial snail and slugs. Egypt Ger Soc J Zool 24D:79-87

Azzam KM (2006) Survey on terrestrial gastropods, their host plants and parasitic nematodes as bio control agents. J Egypt Ger Soc Zool 49D:49-61

Azzam KM, Abd El-Hady EA (2018) Survey on terrestrial molluscs and parasitic nematodes as bio control agents in some governorates. Menoufia J Plant Prot 3:45-52

Azzam KM, Tawfik MFS (2011) First record of the sharp awl snail Opeas pyrgula (Schmacker and Boettger, 1891) and dwarf awl snail Opeas pumilum (Pfeiffer, 1840) in Egypt and their response to climatic change. Egypt J Biol P Contr 21(2):325-330, Proceeding of $3^{\text {rd }}$ Arab conference of applied biological pest control. (2011) ESBCP, Cairo

Baker Skinner Park (2009) North East Florida terrestrial mollusks http://www.ja xshells.org

Camino NB, Gonzàlez SE (2011) Daubaylia n. sp. (Nematoda, Daubayliidae), a parasite of the snail Helix aspersa (Müller) (Mollusca, Pulmonata, Helicidae) from Argentina. Studi Trentini di Sci Natur 88:29-32

Coupland JB (1995) Susceptibility of helicid snails to isolate nematode Phasmarhabditis hermaphrodita from southern France. J Invertebr Pathol 66: 207-208

Cowie RH (2002) Invertebrate invasions on Pacific islands and the replacement of unique native faunas: a synthesis of the land and freshwater snails. Biol Invasions 3(3):119136

Desoky AEASS (2018) Identification of terrestrial gastropods species in Sohag governorate. Egypt Arch Agric Environ Sci 3:4548

Godan D (1983) Pest slugs and snails, biology and control. Verlage, Berlin, p 422

Grewal PS, Grewal SK, Tan L, Adams BJ (2003) Parasitism of molluscs by nematodes: types of associations and evolutionary trends. J Nematol 35:146156

Holovachov O, Camp L, Nadler SA (2015) Sensitivity of ribosomal RNA character sampling in the phylogeny of Rhabditida. J Nematol 47:337-355

Lydeard C, Cowie RH, Ponder WF, Bogan AE, Bouchet P, Clark SA, Cummings KS, Frest TJ, Gargominy O, Herbert DG, Hershler R, Perez KE, Roth B, Seddon M, Strong EE, Thompson FG (2004) The global decline of non-marine molluscs. Bio Sci 54:321-330

Nermut Äô J, Pưža V (2017) Slug parasitic nematodes: biology, parasitism, production and application. In: Abd-Elgawad MMM, Askary TH, Coupland J (eds) Biocontrol agents: entomopathogenic and slug parasitic nematodes. CABI, Wallingford, Boston, pp 533-547

Rae RG, Verdun C, Grewal PS, Robertson JF, Wilson MJ (2007) Biological control of terrestrial molluscs using Phasmarhabditis hermaphrodita-progress and prospects. Pest Manag Sci 63:1153-1164. https://doi.org/10.1002/ps.1424

Singh PR, Couvreur M, Decraemer W, Bert W (2019) Survey of slug parasitic nematodes in east and West Flanders, Belgium and description of Angiostoma gandavensis n. sp. (Nematoda: Angiostomidae) from arionid slugs. J Helminthol:1-11. https://doi.org/10.1017/\$0022149X19000105

Sudhaus W (2018) Various evolutionary avenues of Nematoda to parasitism in gastropoda. Soil Organ 90(3):115-122

Tandingan De Ley I, Holovachov O, McDonnell R, Bert W, Paine TD, De Ley P (2016) Description of Phasmarhabditis californica n. sp. and first report of $P$. papillosa (Nematoda: Rhabditidae) from invasive slugs in the USA. Nematology 18:175-193

Tandingan De Ley I, McDonnell R, Lopez S, Paine TD, De Ley P (2014) Phasmarhabditis hermaphrodita (Nematoda: Rhabditidae), a potential biocontrol agent isolated for the first time from invasive slugs in North America. Nematology 16:1129-1138

Wilson MJ, Burch G, Tourna M, Aalders LT, Barker GM (2012) The potential of a New Zealand strain of Phasmarhabditis hermaphrodita for biological control of slugs. New Zealand Plant Prot 65:161-165

Wilson MJ, Glen DM, George SK (1993) The rhabditid nematode Phasmarhabditis hermphrodita as potential biological control agent for slugs. Biocontrol Sci Tech 3:503-511

\section{Publisher's Note}

Springer Nature remains neutral with regard to jurisdictional claims in published maps and institutional affiliations.

\section{Submit your manuscript to a SpringerOpen ${ }^{\circ}$ journal and benefit from:}

- Convenient online submission

- Rigorous peer review

- Open access: articles freely available online

- High visibility within the field

- Retaining the copyright to your article

Submit your next manuscript at $\boldsymbol{\nabla}$ springeropen.com 